\title{
POLA PERILAKU HIDUP SEHAT TERHADAP KESEJAHTERAAN SANTRI MA'HAD UIN WALISONGO SEMARANG
}

\author{
Rima Qoriah, Susanti, Indah Nur Haliza ${ }^{1}$, Ahmad Fauzan Hidayatullah ${ }^{2}$ \\ ${ }^{1}$ Universitas Islam Negeri Walisongo, Fakultas Psikologi dan Kesehatan, J1. Prof.Dr. Hamka \\ Km 2 Kampus 3 Universitas Islam Negeri Walisongo Semarang, Semarang, Indonesia, Jawa \\ Tengah, Indonesia \\ ${ }^{2}$ Universitas Islam Negeri Walisongo, Fakultas Sains dan Teknologi, Jl. Prof.Dr. Hamka Km \\ 2 Kampus 3 Universitas Islam Negeri Walisongo Semarang, Semarang, Indonesia, Jawa \\ Tengah, Indonesia \\ E-mail: Indah_1807016032@students.walisongo.ac.id \\ afhidayatullah@walisongo.ac.id
}

\begin{abstract}
The pattern of healthy living is a behavior practiced by every individual with his awareness in order to improve his health and participate actively in creating a healthy environment. In this case the authors use the literature review method that refers to journals about healthy behavior patterns and conduct interviews. The purpose of this study was to determine the relationship of healthy behavior patterns seen from the aspect of religion (religious teachings). The results showed that the environment and behavior are the biggest factors that can influence healthy lifestyles. Just as when we live in an environment that is less aware of environmental cleanliness, we will also be influenced to tend to do the same thing with the behavior of the majority of people around us. Conversely, if we live in an environment with high environmental awareness, such as diligently carrying out clean Friday activities, we will also be influenced by the nature of being more phosphitive in our daily behavior. Then the behavior of healthy living will be good and have a good impact on survival.
\end{abstract}

Keyword: Healthy behavior, environment

\begin{abstract}
Abstrak
Pola perilaku hidup sehat merupakan perilaku yang dipraktikan setiap individu dengan kesadarannya guna meningkatkan kesehatannya serta ikut serta berperan aktif dalam menciptakan lingkungan sehat. Dalam hal ini penulis menggunakan metode telaah pustaka yang merujuk pada jurnal tentang pola perilaku sehat serta melakukan wawancara. Tujuan penelitian ini adalah untuk mengetahui hubungan pola perilaku sehat dilihat dari aspek agama (ajaran agama). Hasil penelitian menunjukan bahwa lingkungan dan perilaku merupakan faktor terbesar yang dapat mempengaruhi pola hidup sehat. Seperti halnya ketika kita hidup di lingkungan yan kurang akan kesadaran dalam kebersihan linkungan, maka kita juga akan terpengaruh untuk cenderung melakukan hal yang sama dengan perilaku mayoritas orang-orang yang berada di sekeliling kita. Sebaliknya, jika kita hidup di lingkungan yang kesadaran akan lingkungannya tinggi seperti rajin melakukan kegiatan jum'at bersih maka kita juga akan terpengeruh yang sifatnya lebih fositif dalam perilaku kita sehari-hari. Maka perilaku hidup sehat akan menjadi baik dan berdampak baik pula untuk keberlangsungan hidup.
\end{abstract}

Kata kunci: Perilaku hidup sehat, lingkungan 


\section{PENDAHULUAN}

Kesehatan merupakan faktor penentu keberlangsungan hidup manusia. Bahwasanya badan dan jiwa pada diri manusia, bagai dua sisi berbeda tapi saling memengaruhi satu sama lain. Di dalam badan yang sehat terdapat jiwa yang sehat pula. Sebaliknya didalam jiwa yang sehat terdapat badan yang sehat. Pada dasarnya jiwa merupakan sebagai bentuk arahan cara manusia hidup, baik dan buruknya didasari oleh perbuatan selama hidupnya.

Dalam kemajuan peradaban dan teknologi banyak manusia yang mengabaikan akan kesehatan diri. Salah satu bentuk implikasi dari kesehatan yang diabaikan yaitu mengkonsumsi makanan cepat saji tanpa memperhatikan dampak dari makanan tersebut dikemudian hari.

\begin{abstract}
Banyak penelitian yang telah dilakukan oleh ilmuwan seperti yang dilakukan Icha Pamelia (2018) yang membahas Perilaku Konsumsi Makanan Cepat Saji Pada Remaja Dan Dampaknya Bagi Kesehatan, hasilnya menunjukan bahwa makanan cepat saji dapat meningkatkan resiko beberapa penyakit seperti obesitas, diabetes, bahkan penyakit degeneratif.
\end{abstract}

Bahwasanya Allah memerintahkan umatnya untuk menjaga kesehatan dengan cara menjaga kebersihan dan mensucikan diri. Dengan menjaga kebersihan dan menjaga kesucian akan menciptakan suasana dan

kondisi sehat, apabila kita hidup sehat maka akan memengaruhi kesejahteraan manusia. Manusia dapat dikatakan sehat meliputi fisik (tubuh yang bugar), psikis (berfikir dengan baik dan bertindak sesuai) dan sosial.

Pada kemajuan peradaban, peran santri masih menjadi sesuatu yang sangat penting dalam kehidupan. Para santri ini memiliki tuntutan tugas dan tanggungjawab sebagai insan yang mulia dan warga negara yang baik. Dengan banyaknya tugas dan tanggungjawab tidak menjadikan beban dalam hidup para santri, santri masih dapat menjaga kesehatan dalam diri salah satunya dengan mengkonsumsi makanan yang sehat dan istirahat cukup.

Untuk menjaga kesehatan dalam diri terdapat pola hidup yang benar diantaranya, makanan sehat, istirahat yang cukup dan religiustitas. Religiusitas sangat mempengaruhi pola perilaku sehat, karena didalam agama telah dijelaskan mengenai cara untuk berperilaku sehat sesuai pedoman, apabila santri mengamalkan 
pedoman agama maka ia akan mengkonsumsi makanan yang sehat yang telah dianjurkan. Sehingga jika santri tersebut sudah memiliki pola hidup yang sehat maka akan tercapai kesejahteraan dalam hidupnya.

Kesejahteraan subjektif tersebut suatu peristiwa meliputi kognitif dan emosional individu yang memengaruhi kehidupan manusia seperti bahagia, tenang, tentram sehingga memperoleh kepuasan dalam hidup. Kesejahteraan subjektif memiliki dampak positif pada santri misalnya hubungan positif antara kebutuhan kognitif dengan kepuasan hidup (Coutinho \& Woolery, 2004).

Kesejahteraan subjektif santri dipengaruhi oleh faktor situasional, seperti situasi hidup, kesehatan fisik, dan dukungan keluarga.

Berdasar latarbelakang yang telah disampaikan diatas, penulis menuliskan beberapa rumusan masalah yaitu (1) Apakah perilaku hidup sehat itu dan pelaksanaannya sehingga bisa menciptakan kesejahteraan? (2) Bagaimana ajaran agama terhadap pola perilaku hidup sehat ? (3) Bagaimana dampak ajaran agama terhadap pola hidup sehat santri Ma'had UIN Walisongo? Adapun tujuan penulisan artikel ini untuk mengetahui ajaran agama terhadap pola perilaku hidup sehat, untuk mengetahui pelaksanaan pola perilaku hdiup sehat sehingga menciptakan kesejateraan dan mengetahui pengaruh ajaran agama terhadap pola perilaku hidup sehat di Ma'had Uin Walisongo Semarang.

\section{BAHAN DAN METODE}

Penelitian ini merupakan pendekatan kualitatif, yaitu penelitian yang bersifat deskriptif dan cenderung menggunakan konsep analisis. Terdapat dua variabel yang digunakan dalam penelitian ini, yaitu perilaku hidup sehat sebagai variabel bebas dan kesejahteraan subjektif sebagai variabel terikat.

Masing-masing dari variabel tersebut memiliki aspek pendukung. Aspek dari kesejahteraan subjektif meliputi peristiwa kognitif dan emosional individu yang memengaruhi kehidupan manusia seperti bahagia, tenang, dan tentram sehingga memeroleh kepuasan dalam hidup. Sedangkan aspek dari perilaku hidup sehat meliputi kesehatan fisik, mental dan sosial.

Individu yang memiliki nilai kesejahteraan tinggi maka Ia juga memiliki pola hidup yang sehat. Begitu pula sebaliknya, individu dengan tingkat kesejahteraan subjektif rendah maka 
cenderung memiliki pola hidup yang kurang baik.

\section{HASIL}

Religiusitas erat kaitannya dengan santri. Banyak orang yang berlomba-lomba untuk mencari ilmu, dan pondok adalah salah satu

tempatnya. Tentunya bukan hanya sebatas ilmu umum, tetapi mengenai ilmu keislaman juga. Ketika berada di pondok, seseorang dituntut untuk disiplin, apalagi jika seseorang tersebut mondok dan kuliah sekaligus.

Ma'had Walisongo Semarang merupakan pondok pesantren yang berada di lingkup Universitas Islam Negeri Walisongo Semarang. Dimana universitas tersebut menerapakan unity of science dalam visi misinya. Sebagai tempat mahasiswi belajar, ma'had walisongo menerapkan tiga manajemen yaitu manajemen waktu, manajemen prioritas dan manajemen taqarub ilallah. Dengan ketiga manajemen ini santri diajarkan untuk belajar membagi waktu dengan baik, memilih kegiatan mana yang perlu diprioritaskan dan yang paling utama adalah pendekatan diri kepada Allah SWT.

Dalam menjalankan semua aktivitasnya, para santri diwajibkan untuk mematuhi aturan atau prosedur yang telah berlaku, baik mengenai tugas dan kewajiban serta waktu yang telah ditentukan. Seperti pada kesehariannya, santri wajib mengikuti kegiatan sholat shubuh berjamaah kemudian halaqoh yang berisi khitobah atau speech dari santri yang bertugas, lalu dilanjutkan dengan kuliah pagi (study club) baik bahasa inggris maupun bahasa arab sampai pukul 06.30. Setelah itu, santri diperbolehkan untuk beraktivitas di kampus maupun di luar sampai pukul 17.30. Kemudian dilanjutkan dengan sholat maghrib berjamaah hingga mengaji Al-Qur'an. Lalu mengikuti kegiatan sholat isya berjamaah dan mengaji kitab kuning sampai pada pukul 21.00 .

Adapun kegiatan rutin yang dilaksanakan setiap akhir pekan yaitu senam dan bersih-bersih bersama yang diadakan sebagai pengganti kuliah pagi. Bagi santri yang tidak menaati prosedur, biasanya akan diberi sanksi berupa hafalan atau bersih-bersih. Sedangkan untuk kegiatan piket sehari-hari, para santri hanya berfokus pada kamar yang merekai pakai untuk tidur.

Pola asupan makan di ma'had UIN Walisongo juga baik, para santri akan disajikan makanan diwaktu pagi dan sore dengan menu bervaiasi. 
Jadi, dapat ditarik kesimpulan bahwa ma'had Walisongo tidak hanya mengajarkan nilai-nilai religiusitas saja, namun juga mengajarkan betapa pentingnya menjaga kedisiplinan waktu, memrioritaskan suatu kegiatan, cara pendekatan diri kepada Allah SWT. serta bagaimana cara menjaga kebersihan lingkungan dan kesehatan fisik berupa senam, kesehatan psikologis berupa pendalaman mengenai pengetahuan keislman serta kesehatan sosial yang berupa mampu bersosialisasi dengan para santri maupun pengurus yang jumlahnya lebih dari 400 orang.

\section{PEMBAHASAN}

\section{a. Perilaku Hidup Sehat}

Perilaku hidup sehat merupakan perilaku yang dipraktikan (diterapkan) oleh setiap individu dengan kesadarannya guna meningkatkan kesehatannya serta ikut serta berperan aktif dalam menciptakan lingkungan yang sehat. Pemerintah telah menetapkan Undang-Undang mengenai kesehatan yang terdapat pada pasal 1 ayat 1 UU No. 23 Tahun 1992 yang berbunyi : Kesehatan adalah keadaan sejahtera dari badan, jiwa, dan sosial yang memungkinkan setiap orang hidup produktif secara sosial dan ekonomis.
Sedangkan menurut WHO, kesehatan adalah kondisi dinamis meliputi kesehatan jasmani, rohani, sosial, dan tidak hanya terbebas dari penyakit, cacat, dan kelemahan. Dikatakan sehat secara fisik adalah orang tersebut tidak memiliki gangguan apapun secara klinis.

Lingkungan dan perilaku merupakan faktor terbesar yang dapat memengaruhi pola hidup sehat. Seperti halnya ketika kita hidup di lingkungan yang kurang akan kesadaran dalam kebersihan lingkungan, maka kita juga akan terpengaruh untuk cenderung melakukan hal yang sama dengan perilaku mayoritas orang-orang yang berada di sekeliling kita. Sebaliknya, jika kita hidup di lingkungan yang kesadaran akan lingkungannya tinggi seperti rajin melakukan kegiatan jum'at bersih dan tidak merokok, maka kita juga akan terpengaruh yang sifatnya lebih positif dalam perilaku kita sehari-hari.

Seperti yang sudah dijelaskan mengenai pengertian kesehatan menurut UU No. 23 Tahun 1992 pasal 1 ayat 1 dan WHO, seseorang akan mendapat predikat sehat ketika telah mencakup tiga hal yaitu, sehat secara fisik, psikis dan sosial.

Kesehatan fisik merupakan suatu keadaan baik dimana individu bebas dari 
sakit, seluruh badan serta bagianbagiannya. Kesehatan fisik terwujud apabila sesorang tidak merasa dan mengeluh sakit atau tidak adanya keluhan dan memang secara objektif tidak tampak sakit. Semua organ tubuh berfungsi normal atau tidak mengalami gangguan. Berikut adalah hal-hal yang perlu diperhatikan dalam meningkatkan dan menjaga kesehatan fisik, diantaranya : (1) Rajin berolahraga (2) Menjaga asupan makan dan minuman (3) Menjaga kebersihan badan. Sedangkan kesehatan psikis yaitu adalah kondisi ketika batin berada dalam keadaan tentram dan tenang, sehingga memungkinkan kita untuk menikmati kehidupan sehari-hari dan menghargai orang lain di sekitar. Untuk menjaga kesehatan psikis, kita perlu melakukan halhla berikut ini : (1) menggali dan meningkatkan potensi yang ada dalam diri (2) istirahat yang cukup untuk menghindari stres (3) Berkonsultasi dengan orang yag dipercaya mengenai permasalahan untuk menemukan jalan keluar (4) Meningkatkan nilai religiusitas. Secara sosial, sehat berarti kemampuan seseorang dalam menjalin dan mempertahankan hubungan dengan orang lain. Hubungan kunci ini adalah misalnya hubungan dengan teman dekat, jaringan sosial, teman sekolah, teman kerja atau elemen sosial lainnya. Dimensi ini juga berkaitan dengan kesehatan yang terjadi karena kondisikondisi sosial, politik, ekonomi dan budaya yang melingkupi kehidupan seseorang. Aspek yang terakhir yaitu menjaga kesehatan sosial, berikut adalah cara meningkatkan dan menjaganya : (1) menghargai pendapat orang lain (2) Sering berdiskusi (3) Saling tolong menolong (4) Mematuhi norma yang ada dalam masyarakat.

\section{b. Ajaran Islam Mengenai Perilaku Hidup Sehat}

Kesehatan menurut islam itu sangat penting perannnya. Pada dasarnya manusia diciptakan dibumi ini untuk beribadah dan mengabdi kepada Allah. Pernyataan tersebut telah dijelaskan dalam Surah Az-Zumar ayat 56

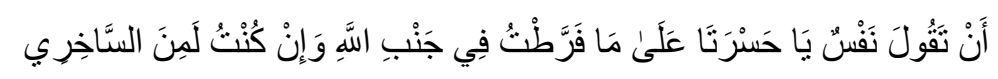

artinya " tidak aku ciptakan jin dan manusia, kecuali untuk beribadah kepadaku”.

Untuk mencapai tujuan tersebut diperlukan 
kesehatan baik jasmani maupun rohani". Dari ayat tersebut terdapat pemikiran yang terkandung didalamnya mengenai kesehatan itu penting diantaranya:

1. Kondisi seseorang dalam beribadah tergantung pada kesehatan Mukmin yang memiliki kesehatan yang baik akan melaksanakan ibadah semaksimal mungkin, dan Allah menyukai mukmin yang yang kuat dan sehat.

2. Minimnya Pengetahuan dan perhatian muslimin terhadap ilmu kesehatan Islam pernah berjaya akan pengetahuannya, namun karena kemunduran akan pengetahuan kesehatan menjadikan manusia tidak mengetahui arti pentingnya kesehatan. Mereka menganggap bahwa kesehatan jika badan sehat dan bugar.

3. Menjadikan Al-Qur'an sebagai pedoman hidup berisi perintah AlQur'an telah menjelaskan mengenai pola hidup sehat yang didasarkan pedoman ayat suci Al-Qur'an. Dengan mengamalkan kandungan ayat suci AlQur'an menjadikan hidup manusia menjadi terarah dan akan mencapai kesejahteraan hidup melalui kesehatan.

4. Ajaran Islam tentang kesehatan Islam telah mengajarkan banyak hal akan kesehatan. Ajaran islam terdapat pada
Al-Qur'an dan hadist. Menurut islam sehat adalah kondisi dimana seseorang baik dari aspek jasmani dan rohani. Dari Al-Qur'an dan As-sunnah mengandung banyak hal yang mengandung pentingnya kesehatan.

5. Perintah Untuk hidup bersih Islam telah memerintahkan umatnya untuk menjaga kebersihan seperti “ Kebersihan adalah sebagian dari Iman" dengan menjaga kebersihan kita juga telah menjalankan keimanan Allah. Dengan kebersihan menjadikan hidup menjadi sehat sehingga terciptanya kesejahteraan manusia.

6. Perintah mengkonsumsi makanan bersih dan halal secukupnya Salah satu contoh ajaran, islam telah mengajarkan bahwa manusia diharuskan untuk mengkonsumsi makanan yang halal dan bersih dan halal serta cukup. Dengan memakan makanan yang halal dan bersih menjadikan tubuh menjadi sehat. Dan memakan manusia diharuskan secukupnya saja, agar tidak terjadi mubazir (tidak dimakan). Apabila kita memakan secara berlebihan bisa dikatakan sebagai serakah, dan dampak bagi kesehatan yaitu akan mengalami penyakit seperti obesitas ataupun diabetes. 
Dalam QS. Al-Baqarah ayat 168

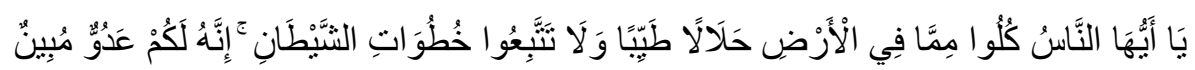

yang artinya " wahai sekalian manusia, makanlah yang halal lagi baik dari apa yang terdapat di bumi dan jangan kamu mengikuti langkah-langkah syaitan, karena sesungguhnya syaitan itu adalah musuh yang nyata bagimu”.

7. Perintah menjaga kesucian Bentuk ajaran islam selanjutnya yaitu menjaga kesucian meliputi lahiriah maupun batiniah. Dengan menjaga kesucian kita akan mendapat manfaat berupa kesehatan. Untuk memperoleh kesehatan tersebut manusia diharuskan menjaga kesucian dari jasmani, rohani atau jiwa. Dalam QS. Al-Baqarah ayat 195 yang artinya “ Dan belanjakanlah (harta bendamu) di jalan Allah, dan janganlah kamu menjatuhkan dirimu sendiri kedalam kebinasaan, dan berbuat baiklah, karena sesungguhnya Allah menyukai orang-orang yang berbuat baik".

8. Larangan merusak alam. Alam merupakan faktor penting dalam menciptakan kesehatan. Faktor alam ini meliputi air, udara,dsb. Tanpa alam manusia tidak mendapatkan udara yang bersih sehingga timbulnya penyakit dan menjadikan manusia menjadi tidak sehat.

\section{c. Konsep Kesahatan menurut Perspektif} Islam

Terdapat ucapan bijaksana Nabi Dawud as antara lain " Kesehatan adalah kerajaan yang tersembunyi", "Kesehatan adalah mahkota di kepala orang-orang yang sehat, yang hanya bisa dilihat oleh orang-orang yang sakit". Serta "Kesehatan adalah harta karun yang tak terlihat". Rasulullah pernah bersabda “ Dua nikmat yang sering tidak diperhatikan oleh kebanyakan manusia yaitu kesehatan dan waktu luang”. Diriwayatkan At-Tirmidzi, Rasulullah bersabda " Barangsiapa bangun dipagi hari dengan badan sehat dan jiwa sehat pula, dan rezekinya dijamin, maka dia seperti orang yang memiliki dunia seluruhnya”. Kesimpulan dari pernyataan diatas yaitu bahwasanya kesehatan merupakan sesuatu yang sangat berharga, dengan kesehatan kita dapat melakukan kesehatan secara maksimal seperti 
beribadah selain itu menciptakan kesejahteran hidup manusia.

\section{d. Dampak Ajaran Agama terhadap} perilaku sehat pada santri ma'had UIN

\section{WALISONGO}

Religiusitas merupakan suatu keadaan, pemahaman dan ketaatan seseorang dalam meyakini suatu agama yang diwujudkan dalam pengamalan nilai, aturan, kewajiban sehingga mendorongnya bertingkah laku, bersikap dan bertindak sesuai dengan ajaran agama dalam kehidupan sehari-hari. Religiusitas meliputi pengetahuan agama, pengalaman agama, perilaku (moralitas) agama, dan sikap sosial keagamaan. Religiusitas memiliki beberapa fungsi antara lain:

1. Fungsi edukatif

Memberikan ajaran-ajaran yang harus dipatuhi. Dalam hal ini bersifat menyuruh dan melarang agar pribadi penganutnya menjadi lebih baik.

2. Fungsi penyelamat

Keselamatan yang dimaksud meliputi dua alam yaitu alam dunia dan akhirat

3. Fungsi pengawasan sosial

Agama dengan ajarannya dianggap sebagai norma, dimana penganutnya harus mematuhinya baik ketika dalam keadaan sendiri maupun di khalayak umum.
4. Fungsi solidaritas

Secara psikologis, para penganut agama yang sama akan memiliki banyak kesamaan dalam kesatuan iman dan kepercayaan. Rasa kesatuan inilah yang dapat membina rasa solidaritas dalam kelompok maupun individual.

5. Fungsi transformatif

Ajaran agama dapat mengubah kehidupan suatu individu ataupun kelompok menjadi kehidupan yang baru sesuai dengan ajaran agama yang dianutnya.

\section{KESIMPULAN}

Perilaku hidup sehat merupakan perilaku individu yang bernilai positif untuk menciptakan kesehatan dalam diri maupun lingkungan sehingga terciptanya kesejahteraan hidup yang dilakukan dalam kehidupan sehari-hari. Pada dasarnya lingkungan dan perilaku menjadi faktor penentu yang mempengaruhi pola hidup sehat. Dalam menjaga kesehatan harus memperhatikan fisik, psikis dan sosial. Ajaran islam telah menjelaskan pentingnya kesehatan yang dijelaskan dalam AlQur'an, menurut islam kesehatan terbentuk karena adanya kebersihan.

Begitupun dengan penerapan di Ma'had Uin Walisongo yang menerapkan Unity Of Science (kesatuan ilmu). Dalam 
praktiknya santri di Ma'had Uin Walisongo tidak hanya menjalankan religiusitas, tetapi juga menerapkan kedisiplinan kepada para santri. Kedisiplinan tersebut berupa manajemen waktu, prioritas, dan man Taqarub Ilallah. Dari kedisiplinan tersebut akan melahirkan sikap kebersihan. Kebersihan salah satu penentu dari kesehatan. Sehingga dapat dikatakan dengan menjaga kebersihan akan menciptakan kesehatan sehingga terbentuknya kesejahteraan dalam santri.

\section{Daftar Pustaka}

1. Zimmer, Z. et al. (2019) 'Religiosity and health: A global comparative study', SSM - Population Health, 7(April 2018). doi: 10.1016/j.ssmph.2018.11.006.

2. Utami, M. S. (2012) 'Religiusitas, koping religius, dan kesejahteraan subjektif', Psikologi, 39(1), pp. 46-66. doi:

10.1016/j.jpainsymman.2006.01.007.

3. Hapsari, D. (2012) 'Pengaruh Lingkungan Sehat, Dan Perilaku Hidup Sehat Terhadap Status Kesehatan',
Bulletin of Health Research, 0(0). doi: 10.22435/bpk.v0i0.2192.

4. Frech, A. (2012) 'Healthy behavior trajectories between adolescence and young adulthood', Advances in Life Course Research, 17(2), pp. 59-68. doi: 10.1016/j.alcr.2012.01.003.

5. Suhrianati (2016) 'Pendidika Perilaku Hidup Bersih Dan Sehat Dalam Presfektif Islam', 3(1), pp. 67-78.

6. Ali, S. et al. (2018) 'POLA HIDUP SEHAT DI PONDOK PESANTREN BAHRUL QUR'AN JONGGRANGAN SUMBERADI MLATI SLEMAN', (2). doi:

10.1051/matecconf/201712107005Putra , R. (2019). Hubungan Antara Konsep Diri Dengan Kecemasan Sosial Pada Narapidana Pria Kasus Narkotika Di Lembaga Pemasyarakatan Kelas Ii A Padang. Psyche .

7. Salim, S. U. (2016). Gambaran Faktor Yang Mempengaruhi Kecemasan Wbp Menjelang Bebas Di Lp Wanita Kelas Ii A Bandung. Ilmu Keperwatan .

8. Stuart, G. (2009). Buku Saku Keperawatan Jiwa. Jakarta: Egc.

9. Utami, W. (2018). Pengaruh Persepsi Stigma Sosial Dan Dukungan Sosial Terhadap Kesejahteraan Psikologis Pada Narapidana . An-Nafs , 183-270. 